\title{
Intercrop advantages of some improved sweet potato + soybean in Makurdi, Benue State, Nigeria
}

\author{
Moses O. EGBE* ${ }^{*}$ Philip O. OSANG \\ Department of Crop Production, University of Agriculture,P.M.B.2373, Makurdi \\ *E-mail: onyiloegbe@yahoo.co.uk
}

Keywords: Sweet potato; soybean; variety; planting density; intercropping

\begin{abstract}
Field trials were conducted during 2011 and 2012 cropping seasons at the Teaching and Research Farm of the University of Agriculture Makurdi, Benue State located in Southern Guinea Savanna of Nigeria. The objective of the study was to evaluate the response of some improved sweet potato varieties planted at three densities to intercropping with soybean. The experiment was a $2 \times 3 \times 3$ split-split plot laid out in a randomized complete block design with three replications. The main plot consisted of two cropping systems [sole cropping (sweet potato, soybean) and intercropping (sweet potato + soybean). The sub-plot consisted of three sweet potato varieties (CIP440037, NRSP/05/007C and CIP440141). The sub-sub-plot treatment comprised of three sweet potato planting densities (25,000 plants/ha, 33,000 plants/ha and 50,000 plants/ha). Intercropping severely depressed the yields of both sweet potato varieties and the soybean component, such that intercrop yields were rarely above $50 \%$ of sole crop yields, irrespective of the sweet potato variety used. The number and weight of the sweet potato component was not significantly affected at the planting density of 50,000 plants/ha. Indices used to measure intercrop advantage showed that intercropping these sweet potato varieties with soybean was biologically efficient and percentage land saved varied from 23.08 and 32.43. Soybean was more competitive than sweet potato at all densities tested.
\end{abstract}

\section{INTRODUCTION}

Sweet potato (Ipomoea batatas (L) Lam) is an important staple food crop worldwide due to its high yield and wide spread adaptation (Bouwkamp, 1985). It is the second most important root tuber crop in the world after Irish potato (Dantata, 2010). It ranks third in production area among the root and tuber crops, following cassava and yam in Nigeria (Anyaebunam et al., 2008). The wide spread cultivation of sweet potato in small farms in different regions of the world shows its potential for inclusion in cropping systems suited to the agronomic and socio-economic condition of the resource poor farmer.

Soybean (Glycine max (L) Merr.) is an integral component of the traditional cropping systems of the Southern Guinea Savanna agro- ecological zone of Nigeria, due to its beneficial effects on soil fertility and as a source of nutritious food (Henriet et al., 1997). The importance of soybean is predicated on its high nutritious quality with respect to its protein and oil. Oil from soybean is of high quality, being 85 percent unsaturated and cholesterol free and hence is suitable for heart disease patients (Onochei, 1975).

Plant characteristics that are considered useful in monoculture may not be so under intercropping. According to Davis and Wooley (1993), the traits required for intercropping are those which enhance the complimentary effect between species and minimize the intercrop competition. Egbe and Idoko (2009) observed that sweet potato varieties commonly cultivated by farmers in Southern Guinea Savannah zone of Nigeria often result in low root yield (3-9 t/ha) compared to the average world yield of $14.9 \mathrm{t} / \mathrm{ha}$ (FAO,2001). Yield advantages of intercropping sweet potato with some crops ( maize, okra, pigeonpea) have been reported by some authors ( Ossom, 2010; Ijoyah and Jimba,2011; Egbe and Idoko, 2009). Similar findings have been reported for soybean intercropped with such other crops as maize, sorghum and castor (Ennin et al., 2002; 
Akunda, 2001; Evans and Streedharran, 1982). Also, the performance of sweet potato and soybean as affected by cropping sequence in northern guinea savanna has been reported ( Babatunde et al.,2011). However, documented scientific information on yield advantages derived from sweet potato + soybean intercropping as influenced by variety and planting density is scarce in Southern Guinea Savanna of Nigeria. Therefore, the objective of this experiment was to determine the suitability of some improved sweet potato varieties planted at varying densities for intercropping with soybean in Makurdi, with a view to enhance productivity of the intercropping systems and food security in Southern Guinea Savanna of Nigeria.

\section{MATERIALS AND METHODS}

\subsection{Study Area}

Field trials were conducted during 2011 and 2012 cropping seasons at the Teaching and Research Farm of the University of Agriculture Makurdi (GPS: N07 47.270', E $07^{0} 37.667^{\prime}$, Elevation $100 \mathrm{msl})$, Benue State located in Southern Guinea Savanna of Nigeria. The objective of the study was to evaluate the response of some improved sweet potato varieties planted at three densities to intercropping with soybean.

\subsection{Soil Sampling and Analysis}

Ten core samples were collected from different sections of the experimental field from a depth of $0-30 \mathrm{~cm}$ and bulked into a composite sample and used for the estimation of the physical and chemical properties of the soil (Table1) before planting in each of the experimental years.

Table 1. Physical and Chemical properties of the surface soil $(0-30 \mathrm{~cm})$ at the experimental site in Makurdi

\begin{tabular}{|c|c|c|c|}
\hline \multirow[t]{2}{*}{ Particulars } & Values & & \multirow{2}{*}{ Methods } \\
\hline & 2011 & 2012 & \\
\hline Sand $(\%)$ & 84.40 & 85.02 & Hydrometer Method (Bouyoucos, 1962) \\
\hline Silt $(\%)$ & 8.45 & 7.88 & \\
\hline Clay $(\%)$ & 7.15 & 7.10 & \\
\hline Textural class & $\begin{array}{l}\text { Sandy } \\
\text { loam }\end{array}$ & $\begin{array}{l}\text { Sandy } \\
\text { loam }\end{array}$ & \\
\hline $\mathrm{pH}\left(\mathrm{H}_{2} \mathrm{O}\right)$ & 6.20 & 6.30 & Glass electrode pH meter (Jackson,1973) \\
\hline $\begin{array}{l}\text { Organic carbon } \\
(\mathrm{g} / \mathrm{kg})\end{array}$ & 1.52 & 1.41 & $\begin{array}{l}\text { Improved Chromic Acid Digestion and Spectrophotometric } \\
\text { Method (Heanes,1984) }\end{array}$ \\
\hline $\begin{array}{l}\text { Organic matter } \\
(\mathrm{g} / \mathrm{kg})\end{array}$ & 2.62 & 2.44 & Multiplying the organic carbon figure by 1.724 \\
\hline Total N (g/kg) & 0.96 & 0.88 & Phenols Color Formation Method (Chaykin,1969) \\
\hline $\begin{array}{l}\text { Available } \mathrm{P}(\mathrm{cmol} / \mathrm{kg} \\
\text { soil) }\end{array}$ & 6.50 & 5.80 & Bray 1 Method (Bray and Kurtz,1945) \\
\hline $\mathrm{Ca} 2+(\mathrm{cmol} / \mathrm{kg}$ soil $)$ & 2.41 & 2.11 & Method described by Jou (1983). \\
\hline $\mathrm{Mg} 2+(\mathrm{cmol} / \mathrm{kg}$ soil & 1.0 & 1.02 & Method described by Tel and Rao (1982). \\
\hline $\mathrm{K}+(\mathrm{cmol} / \mathrm{kg}$ soil $)$ & 0.32 & 0.30 & Method described by Jou (1982). \\
\hline $\mathrm{CEC}(\mathrm{cmol} / \mathrm{kg}$ soil $)$ & 3.73 & 3.43 & Summation Method \\
\hline
\end{tabular}

\subsection{Treatments and Experimental Design}

The experiment was a $2 \times 3 \times 3$ split-split plot laid out in a randomized complete block design with three replications. The main plot consisted of two cropping systems [sole cropping (sweet potato, soybean) and intercropping (sweet potato + soybean). The sub-plot consisted of three sweet potato varieties (CIP440037, NRSP/05/007C and CIP440141, designated as V1, V2, V3, respectively). The sub-sub-plot treatment comprised of three sweet potato planting densities $(25,000$ plants/ha, 33,000 plants/ha and 50,000 plants/ha designated as D1, D2, and D3, respectively). These three densities were established on the field by sowing the sweet potato at $1 \mathrm{~m} \times 25 \mathrm{~cm} \times 1$ plant/stand, $1 \mathrm{~m} \times 30 \mathrm{~cm} \times 1$ plant/stand and $1 \mathrm{~m}$ x $40 \mathrm{~cm} \times 1$ plant/stand, respectively in both sole 
and intercrop treatments. Sweet potato varieties were obtained from National Root Crop Research Institute sub- station Otobi while soybean var. TGX 1448-2E was obtained from National Cereal Research Institute sub - station Yandev, Gboko.

\subsection{Agronomic Practices}

The land was manually cleared and ridged using cutlasses and hoes.Ridges were constructed $1 \mathrm{~m}$ apart. Gross plot consisted of 4 ridges, $3 \mathrm{~m}$ long $\left(12 \mathrm{~m}^{2}\right)$ and the net plot was made up of the inner two ridges $\left(6 \mathrm{~m}^{2}\right)$. Planting was done on the $7^{\text {th }}$ and $9^{\text {th }}$ of July 2011 and 2012 , respectively. Sweet potato vine cuttings measuring $30 \mathrm{~cm}$ with at least 4 nodes were planted by the side of the ridge at specified spacing to obtain the required planting density for each treatment. Soybean was sown at the top of the ridge. Soybean seeds were drilled and later thinned to one plant per stand in both sole and intercrop systems at a spacing of $100 \mathrm{~cm} \times 5 \mathrm{~cm}(200,000$ plants/ha). Fertilizer was applied at land preparation by broadcasting at the rate of $300 \mathrm{~kg}$ NPK: 15:15:15 per hectare before splitting of the ridges as recommended by BNARDA (2003). Two manual weeding were done at 3 and 6 weeks after planting (w.a.p.) using traditional hoes. Earthening up of the sweet potato component was done from 8 w.a.p. until harvest, as the need arose. Soybean was harvested at physiological maturity, when all the pods had turned golden yellow and $90 \%$ of the leaves had turned brown. Sweet potato was harvested when most of the leaves had turned yellow.

\subsection{Evaluation of intercrop productivity}

The productivity indices used to estimate the intercrop advantage were:

(i) Land equivalent ratio (LER), an accurate assessment of the biological efficiency of the intercropping situation (Ofori and Stern,1987). LER was estimated as:

$$
\mathrm{LER}=(\mathrm{Yab} / \mathrm{Yaa})+(\mathrm{Yba} / \mathrm{Ybb})
$$

Where, Yaa and Ybb are yields as sole crops of sweet potato and soybean and Yab and Yba as intercrops of sweet potato and soybean. LER figures greater than 1 are considered advantageous.

(ii) Percentage land saved indicates how much land is saved by intercropping as opposed to sole cropping. This was calculated as described by Willey (1985):

$$
\% \text { Land saved }=100-1 / \text { LER } \times 100
$$

(iii) Competitive ratio (CR) measures the degree with which one component crop competes with the other in intercropping situation. This was estimated using the formula proposed by Willey et al. (1980), which was calculated as:

$$
\mathrm{CRa}=\mathrm{Xab} / \mathrm{Xaa} \times \mathrm{Zab} \div \mathrm{Xab} / \mathrm{Xbb} \times \mathrm{Zba}
$$

Where, $\mathrm{Xaa}=$ yield of pure stand of sweet potato; $\mathrm{Xab}=$ intercrop yield of sweet potato; Xbb $=$ pure stand yield of soybean; $\mathrm{Xba}=$ intercrop yield of soybean; Zab and Zba are sown proportions sweet potato and soybean in the intercropping systems.

\subsection{Data Collection and Analysis.}

At harvest, data on fodder weight, the number and weight of marketable roots of sweet potato were collected. Also, at harvest, the number of pods/plant, seeds/pod, one-hundred seed weight and the grain yield of soybean component were measured.

The data generated were analyzed using GENSTAT Statistical Software. Fisher's Least Significant Difference (FLSD) was used for means separation at the probability level of 5\% whenever differences between treatment means were significant. Land Equivalent Ratio (LER) as described by Ofori and Stern (1987), Competitive Ratio (CR) as proposed by Willey and Rao (1980) and percentage (\%) land saved as described by Willey (1985) were used to determine the productivity of the intercropping systems.

\subsection{RESULTS}

\subsection{Fodder weight of sweet potato intercropped with soybean}

The interactions of cropping systems $\mathrm{x}$ variety $\mathrm{x}$ density, cropping systems $\mathrm{x}$ density and variety $\mathrm{x}$ density had no significant $(\mathrm{P} \geq 0.05)$ effects on the fodder weight of sweet potatoes in both 
2011 and 2012, but cropping systems x variety had the opposite trend in 2012. Also, the main effect of variety on the fodder weight of sweet potato was not significant in 2011, but it was in 2012 . However, the main effect of density on the fodder weight of sweet potato proved significant $(\mathrm{P} \leq$ $0.05)$ in both years.

Tables 2 and 3 present the interaction effects of cropping systems $\mathrm{x}$ variety and the main effect of density on the fodder weight produced by sweet potatoes in Makurdi in both experimental years, respectively. Sole cropping produced higher fodder weight than intercropping in all the sweet potato varieties tested, and this was particularly significant in 2012. CIP440141 (V3) gave the highest fodder weight, while CIP440037 (V1) produced the lowest fodder weight in both years of the study. Fodder weight of sweet potato decreased with increase in density from D1 to D3 in both 2011 and 2012.

Table 2. Influence of cropping systems x variety on the fodder weight $(\mathrm{t} / \mathrm{ha})$ of sweet potato in Makurdi in 2011 and 2012.

\begin{tabular}{|c|c|c|c|c|c|c|c|c|}
\hline \multirow[t]{3}{*}{ Cropping systems } & \multicolumn{8}{|c|}{ Number of marketable roots } \\
\hline & \multicolumn{4}{|c|}{2011} & \multicolumn{4}{|l|}{2012} \\
\hline & V1 & $\mathrm{V} 2$ & V3 & Mean & V1 & V2 & V3 & Mean \\
\hline Sole & 15.30 & 10.18 & 19.05 & 14.84 & 22.48 & 16.20 & 12.37 & 17.02 \\
\hline Intercrop & 7.92 & 7.71 & 10.22 & 8.62 & 11.15 & 7.81 & 5.84 & 8.27 \\
\hline Mean & 11.61 & 8.94 & 14.63 & 11.73 & 8.90 & 10.25 & 18.77 & 12.64 \\
\hline FLSD $(0.05)$ & & & & & & & & \\
\hline CRS & 6.37 & & & & 11.00 & & & \\
\hline VAR & 5.03 & & & & 3.78 & & & \\
\hline CRS X VAR & 6.53 & & & & 8.49 & & & \\
\hline
\end{tabular}

$\mathrm{V} 1=\mathrm{CIP} 440037 ; \mathrm{V} 2=\mathrm{NRSP} / 05 / 007 \mathrm{C} ; \mathrm{V} 3=\mathrm{CIP} 440141$

$\mathrm{CRS}=$ Cropping systems; VAR $=$ Variety; $\mathrm{DEN}=$ Density

Table 3: Effects of density on the fodder weight ( $t /$ ha) of sweet potato in Makurdi in 2011 and 2012.

\begin{tabular}{l|l|l|l}
\hline \multirow{2}{*}{ Density } & \multicolumn{2}{|c|}{ Fodder weight } & Mean \\
\cline { 2 - 3 } & 2011 & 2012 & \\
\hline D1 & 16.24 & 16.82 & 16.53 \\
D2 & 10.95 & 12.01 & 11.48 \\
D3 & 8.00 & 9.10 & 8.55 \\
Mean & 11.73 & 12.64 & 12.19 \\
FLSD (0.05) & 4.37 & 4.83 & \\
\hline
\end{tabular}

$\mathrm{D} 1=25,000$ plants/ha; $\mathrm{D} 2=33,000$ plants/ha; D3 $=50,000$ plants/ha

\subsection{Number of marketable roots/plant of sweet potato intercropped with soybean}

The interactions of cropping systems $\mathrm{x}$ variety $\mathrm{x}$ density and variety $\mathrm{x}$ density did not show any significant effects on the number of roots/per plant of sweet potato intercropped with soybean in both 2011 and 2012, but cropping systems x density did in both years. Cropping systems $\mathrm{x}$ variety had significant effects on the number of roots/per plant of sweet potato intercropped with soybean only in 2012. The main effect of variety on the number of roots/per plant of sweet potato intercropped with soybean was significant in both experimental years, while that of cropping systems was significant only in 2012. Density had no significant effects on the number of roots/per plant of sweet potato intercropped with soybean in both 2011 and 2012.

Table 4 presents the results of the influence of cropping systems $x$ variety on the number of roots produced per plant of sweet potato intercropped with soybean in Makurdi in both 2011 and 2012 ,although the influence was not significant in 2011. The number of marketable roots/plant of sweet potato had a mean of 1.83 and 2.63 in 2011 and 2012, respectively. Intercropping depressed the number of roots/plant of all the sweet potato varieties used in the study. The depression was 
particularly significant in V2 in 2012. In both years, V2 consistently had the highest number of roots/plant of sweet potato in Makurdi.

Table 4. Effect of cropping systems $x$ variety on the number of marketable roots per plant of sweet potato intercropped with soybean in Makurdi in 2011 and 2012

\begin{tabular}{|c|c|c|c|c|c|c|c|c|}
\hline \multirow[t]{3}{*}{ Cropping systems } & \multicolumn{8}{|c|}{ Number of marketable roots } \\
\hline & \multicolumn{4}{|c|}{2011} & \multicolumn{4}{|c|}{2012} \\
\hline & V1 & V2 & V3 & Mean & V1 & $\mathrm{V} 2$ & V3 & Mean \\
\hline Sole & 1.67 & 4.67 & 2.44 & 2.93 & 2.67 & 6.67 & 3.00 & 4.11 \\
\hline Intercrop & 0.33 & 1.56 & 0.33 & 0.74 & 0.44 & 2.11 & 0.89 & 1.15 \\
\hline Mean & 1.00 & 3.11 & 1.39 & 1.83 & 1.56 & 4.39 & 1.94 & 2.63 \\
\hline FLSD $(0.05)$ & & & & & & & & \\
\hline CRS & 2.65 & & & & 3.10 & & & \\
\hline VAR & 1.20 & & & & 1.05 & & & \\
\hline CRS X VAR & 2.09 & & & & 2.39 & & & \\
\hline
\end{tabular}

$\mathrm{V} 1=\mathrm{CIP} 440037 ; \mathrm{V} 2=\mathrm{NRSP} / 05 / 007 \mathrm{C} ; \mathrm{V} 3=\mathrm{CIP} 440141$

$\mathrm{CRS}=$ Cropping systems; VAR $=$ Variety; $\mathrm{DEN}=$ Density

Table 5 shows the results of cropping systems $x$ density interaction effects on the number of marketable roots produced by sweet potato intercropped with soybean in Makurdi in 2011 and 2012. Intercropping reduced the number of marketable roots of sweet potato at all densities tested, and this was significant at D1 and D2 in both years of experimentation. At D3 the reduction was insignificant in both years. The number of marketable roots/plant decreased with increased planting density under sole cropping, but had an opposite trend under intercropping in both years (Table 5).

The mean square estimates showed that the interaction effects of cropping systems $\mathrm{x}$ variety $\mathrm{x}$ density, cropping systems $\mathrm{x}$ density, variety $\mathrm{x}$ density and the main effects of density on the marketable root weight were not significant $(\mathrm{P} \geq 0.05)$, but the interaction effects of cropping systems $\mathrm{x}$ variety and the main effects of cropping systems and variety were significant $(\mathrm{P} \leq 0.05)$ in both years. Sole crop sweet potato varieties gave significantly higher marketable root weight than the intercrop treatments in both years of the study (Table 6). V2 consistently gave higher marketable root weight than the other two varieties in both cropping systems in both years (Table $6)$.

Table 5. Cropping systems $x$ density interaction effects on the number of marketable roots per plant of sweet potato intercropped with soybean in Makurdi in 2011 and 2012.

\begin{tabular}{|c|c|c|c|c|c|c|c|c|}
\hline \multirow[t]{3}{*}{ Cropping systems } & \multicolumn{8}{|c|}{ Number of marketable roots } \\
\hline & \multicolumn{4}{|c|}{2011} & \multicolumn{4}{|c|}{2012} \\
\hline & D1 & D2 & D3 & Mean & D1 & D2 & D3 & Mean \\
\hline Sole & 3.78 & 3.11 & 1.89 & 2.93 & 5.11 & 4.22 & 3.00 & 4.11 \\
\hline Intercrop & 0.44 & 0.56 & 1.22 & 0.74 & 0.78 & 0.78 & 1.89 & 1.15 \\
\hline Mean & 2.11 & 1.83 & 1.56 & 1.83 & 2.94 & 2.50 & 2.44 & 2.63 \\
\hline FLSD $(0.05)$ & & & & & & & & \\
\hline CRS & 2.65 & & & & 3.10 & & & \\
\hline $\mathrm{DEN}$ & 0.81 & & & & 1.23 & & & \\
\hline CRS X DEN & 2.01 & & & & 2.37 & & & \\
\hline
\end{tabular}

$\mathrm{D} 1=25,000$ plants/ha; D2 $=33,000$ plants $/$ ha; $\mathrm{D} 3=50,000$ plants $/$ ha

$\mathrm{CRS}=$ Cropping systems; DEN $=$ Density 


\subsection{Weight of marketable roots of sweet potato intercropped with soybean}

Table 6. Weight of marketable roots of sweet potato intercropped with soybean as affected by cropping systems x variety in Makurdi in 2011 and 2012.

\begin{tabular}{l|l|l|l|l|l|l|l|l}
\hline \multirow{2}{*}{ Cropping systems } & \multicolumn{9}{l}{ Marketable root weight (t/ha) } \\
\cline { 2 - 8 } & \multicolumn{2}{|l|}{2011} & \multicolumn{2}{l}{ 2012 } & \multicolumn{3}{l}{} \\
\cline { 2 - 8 } Sole & V1 & V2 & V3 & Mean & V1 & V2 & V3 & Mean \\
Intercrop & 5.56 & 8.78 & 6.44 & 6.93 & 2.67 & 6.67 & 3.00 & 4.11 \\
Mean & 0.33 & 1.56 & 0.33 & 0.74 & 0.44 & 2.11 & 0.89 & 1.15 \\
FLSD (0.05) & 2.95 & 5.17 & 3.39 & 3.84 & 1.56 & 4.39 & 1.95 & 2.63 \\
CRS & & & & & & & & \\
VAR & 3.60 & & & & 3.10 & & & \\
CRS X VAR & 1.33 & & & & 1.05 & & & \\
\hline
\end{tabular}

V1= CIP440037; V2 = NRSP/05/007C; V3 = CIP440141

$\mathrm{CRS}=$ Cropping systems; VAR $=$ Variety

Intercrop sweet potato varieties had significantly lower marketable root weights than the sole systems at all densities tested in both years (Table7). Intercrop marketable root weight at D3 was higher than those at the other two densities in the two years of experimentation. Percentage yield of intercrop as a proportion of sole crop yield was consistently higher at D3 than all other densities and this was particularly so in 2012.

Table 7.Weight of marketable root weight of sweet potato as affected by cropping systems $\mathrm{x}$ density in Makurdi in 2011 and 2012.

\begin{tabular}{|c|c|c|c|c|c|c|c|c|}
\hline \multirow[t]{3}{*}{ Cropping systems } & \multicolumn{8}{|c|}{ Marketable root weight (t/ha) } \\
\hline & \multicolumn{4}{|c|}{2011} & \multicolumn{4}{|l|}{2012} \\
\hline & D1 & D2 & D3 & Mean & D1 & D2 & D3 & Mean \\
\hline Sole & 2.78 & 7.44 & 5.26 & 5.16 & 5.11 & 4.22 & 3.00 & 4.11 \\
\hline Intercrop & 0.44 & 0.56 & 1.22 & 0.74 & 0.78 & 0.78 & 1.89 & 1.15 \\
\hline Mean & 1.61 & 4.00 & 3.24 & 2.95 & 2.95 & 2.50 & 2.45 & 2.63 \\
\hline$\%$ intercrop yield of sole & 15.83 & 7.53 & 23.19 & - & 15.26 & 18.48 & 63.00 & - \\
\hline FLSD $(0.05)$ & & & & & & & & \\
\hline CRS & 3.59 & & & & 3.10 & & & \\
\hline DEN & 0.89 & & & & 1.23 & & & \\
\hline CRS X DEN & 2.81 & & & & 2.37 & & & \\
\hline
\end{tabular}

$\mathrm{D} 1=25,000$ plants/ha; D2 $=33,000$ plants/ha; D3 $=50,000$ plants $/$ ha

$\mathrm{CRS}=\mathrm{CROPPING}$ SYSTEMS

\subsection{Soybean component}

\subsection{Number of pods per plant of soybean intercropped with sweet potato varieties.}

The interactions of cropping systems $\mathrm{x}$ variety $\mathrm{x}$ density, variety $\mathrm{x}$ density had no significant effects on the number of pods/plant and the grain yield of soybean in Makurdi in 2011 and 2012; neither did the main effects of variety density. However, the interaction effects of cropping systems $\mathrm{x}$ variety and cropping systems $\mathrm{x}$ density on the number of pods/plant and the grain yield of soybean were significant. The main effect of cropping systems on both pods/plant and grain yield was significant in both years.

Pods/plant averaged 71.25 in 2011 and 62.85 in 2012 (Table 8). The number of pods/plant of soybean intercropped with sweet potato was significantly reduced by intercropping, irrespective of the variety of sweet potato used in both years of the experiment (Table 8). Table 9 shows that intercropping depressed the number of pods/plant of soybean at all densities tested in both reporting years. 
Table 8. Influence of cropping systems and sweet potato varieties on the number of pods/plant of soybean component in Makurdi in 2011 and 2012.

\begin{tabular}{|c|c|c|c|c|c|c|c|c|}
\hline \multirow{3}{*}{$\begin{array}{l}\text { Cropping } \\
\text { systems }\end{array}$} & \multicolumn{8}{|c|}{ Number of pods/plant of soybean } \\
\hline & \multicolumn{4}{|c|}{2011} & \multicolumn{4}{|c|}{2012} \\
\hline & V1 & V2 & V3 & Mean & V1 & V2 & V3 & Mean \\
\hline Sole & 84.80 & 93.10 & 81.10 & 86.33 & 69.10 & 75.20 & 78.80 & 74.37 \\
\hline Intercrop & 43.40 & 68.80 & 56.30 & 56.17 & 41.60 & 51.70 & 60.70 & 51.33 \\
\hline Mean & 64.10 & 80.95 & 68.70 & 71.25 & 55.35 & 63.45 & 69.75 & 62.85 \\
\hline $\begin{array}{l}\text { FLSD }(0.05) \\
\text { CRS }\end{array}$ & 1668 & & & & 1054 & & & \\
\hline & & & & & & & & \\
\hline VAR. & 22.92 & & & & 11.55 & & & \\
\hline CRS X VAR & 27.21 & & & & 16.86 & & & \\
\hline
\end{tabular}

$\mathrm{V} 1=\mathrm{CIP} 440037 ; \mathrm{V} 2=\mathrm{NRSP} / 05 / 007 \mathrm{C} ; \mathrm{V} 3=\mathrm{CIP} 440141$

$\mathrm{CRS}=$ Cropping systems; VAR $=$ Variety; DEN $=$ Density

Table 9. Influence of cropping systems and sweet potato densities on the number of pods/plant of soybean component in Makurdi in 2011 and 2012.

\begin{tabular}{|c|c|c|c|c|c|c|c|c|}
\hline \multirow{4}{*}{$\begin{array}{l}\text { Cropping } \\
\text { systems }\end{array}$} & \multicolumn{8}{|c|}{ Number of pods/plant } \\
\hline & \multicolumn{8}{|c|}{ Sweet potato planting density } \\
\hline & \multicolumn{4}{|c|}{2011} & \multicolumn{4}{|c|}{2012} \\
\hline & $\mathrm{D}_{1}$ & $\mathrm{D}_{2}$ & $\mathrm{D}_{3}$ & Mean & $\mathrm{D}_{1}$ & $\mathrm{D}_{2}$ & $\mathrm{D}_{3}$ & Mean \\
\hline Sole & 92.30 & 82.10 & 84.60 & 86.33 & 74.10 & 71.20 & 77.80 & 74.37 \\
\hline Intercrop & 56.50 & 53.90 & 58.10 & 56.17 & 58.20 & 49.30 & 46.60 & 51.37 \\
\hline Mean & 74.40 & 68.00 & 71.35 & 71.25 & 66.15 & 60.25 & 62.20 & 62.86 \\
\hline FLSD $(0.05)$ & & & & & & & & \\
\hline CRS & 3.97 & & & & 19.54 & & & \\
\hline DEN & 2.88 & & & & 10.63 & & & \\
\hline CRS X DEN & 3.89 & & & & 10.33 & & & \\
\hline
\end{tabular}

$\mathrm{D} 1=25,000$ plants/ha; D2 $=33,000$ plants/ha; D3 $=50,000$ plants $/$ ha

$\mathrm{CRS}=\mathrm{CROPPING}$ SYSTEMS

\subsection{Grain yield of soybean}

Tables 10 and 11 present the interaction effects of cropping systems $\mathrm{x}$ variety and cropping systems $x$ density on the grain yield of soybean intercropped with sweet potato, respectively. The grain yield of soybean averaged $1.26 \mathrm{t} / \mathrm{ha}$ in 2011 and $1.01 \mathrm{t} / \mathrm{ha}$ in 2012. Intercropping decreased the grain yields of the soybean component irrespective of the sweet potato variety and at all densities. 
Table 10. Grain yield (t/ha) of soybean as influenced by cropping systems $x$ variety of sweet potato in Makurdi in 2011 and 2012.

\begin{tabular}{|c|c|c|c|c|c|c|c|c|}
\hline \multirow{3}{*}{$\begin{array}{l}\text { Cropping } \\
\text { systems }\end{array}$} & \multicolumn{8}{|c|}{ Grain yield of soybean } \\
\hline & \multicolumn{4}{|c|}{2011} & \multicolumn{4}{|c|}{2012} \\
\hline & $\mathrm{V}_{1}$ & $\mathrm{~V}_{2}$ & $\mathrm{~V}_{3}$ & Mean & $\mathrm{V}_{1}$ & $\mathrm{~V}_{2}$ & $\mathrm{~V}_{3}$ & Mean \\
\hline Sole & 1.59 & 1.55 & 1.59 & 1.57 & 1.25 & 1.33 & 1.40 & 1.33 \\
\hline Intercrop & 0.94 & 0.84 & 1.03 & 0.94 & 0.58 & 0.67 & 0.83 & 0.69 \\
\hline Mean & 1.27 & 1.20 & 1.31 & 1.26 & 0.92 & 1.00 & 1.12 & 1.01 \\
\hline FLSD $(0.05)$ & & & & & & & & \\
\hline CRS & 0.40 & & & & 0.60 & & & \\
\hline VAR & 0.72 & & & & 0.16 & & & \\
\hline DEN & 0.12 & & & & 0.17 & & & \\
\hline CRS X VAR & 0.38 & & & & 0.48 & & & \\
\hline
\end{tabular}

$\mathrm{V} 1=\mathrm{CIP} 440037 ; \mathrm{V} 2=\mathrm{NRSP} / 05 / 007 \mathrm{C} ; \mathrm{V} 3=\mathrm{CIP} 440141$

$\mathrm{CRS}=$ Cropping systems; VAR $=$ Variety

Table 11. Grain yield ( $t / h a)$ of soybean as influenced by cropping systems $x$ density of sweet potato in Makurdi in 2011 and 2012.

\begin{tabular}{|c|c|c|c|c|c|c|c|c|}
\hline \multirow{3}{*}{$\begin{array}{l}\text { Cropping } \\
\text { systems }\end{array}$} & \multicolumn{8}{|c|}{ Grain yield of soybean } \\
\hline & \multicolumn{4}{|c|}{2011} & \multicolumn{4}{|c|}{2012} \\
\hline & $\overline{D_{1}}$ & $\mathrm{D}_{2}$ & $\mathrm{D}_{3}$ & Mean & $\mathrm{D}_{1}$ & $\overline{\mathrm{D}_{2}}$ & $\overline{\mathrm{D}_{3}}$ & Mean \\
\hline Sole & 1.64 & 1.53 & 1.56 & 1.57 & 1.30 & 1.26 & 1.42 & 1.33 \\
\hline Intercrop & 0.94 & 0.94 & 0.93 & 0.94 & 0.74 & 0.65 & 0.69 & 0.69 \\
\hline $\begin{array}{l}\text { Mean } \\
\text { FLSD (0.05) }\end{array}$ & 1.29 & 1.24 & 1.25 & 1.26 & 1.02 & 0.96 & 1.06 & 1.01 \\
\hline CRS & 0.40 & & & & 0.60 & & & \\
\hline VAR & 0.27 & & & & 0.16 & & & \\
\hline DEN & 0.12 & & & & 0.17 & & & \\
\hline CRS X DEN & 0.31 & & & & 0.46 & & & \\
\hline
\end{tabular}

\subsection{Assessment of productivity of intercropping sweet potato varieties with soybean.}

Land equivalent ratio (LER) values were above 1.00 in all the intercrop combinations (Figure 1). Intercropped NARSP/05/007C (V2) with soybean produced the highest LER, but this was not significantly different from those of the other intercropped sweet potato varieties [CIP440037 (V1), CIP440141 (V3)] in both years of the study.Competitive ratio figures of soybean were consistently higher than those of the sweet potato component in both years (Figure 2).

Figure 3 indicates that percentage land saved by intercropping was highest when NARSP/05/007C (V2) was intercropped with soybean in both years, although this was statistically at par with the other varieties[CIP440037(V1),CIP440141(V3)] of intercropped sweet potato with soybean in Makurdi in 2011 and 2012. 


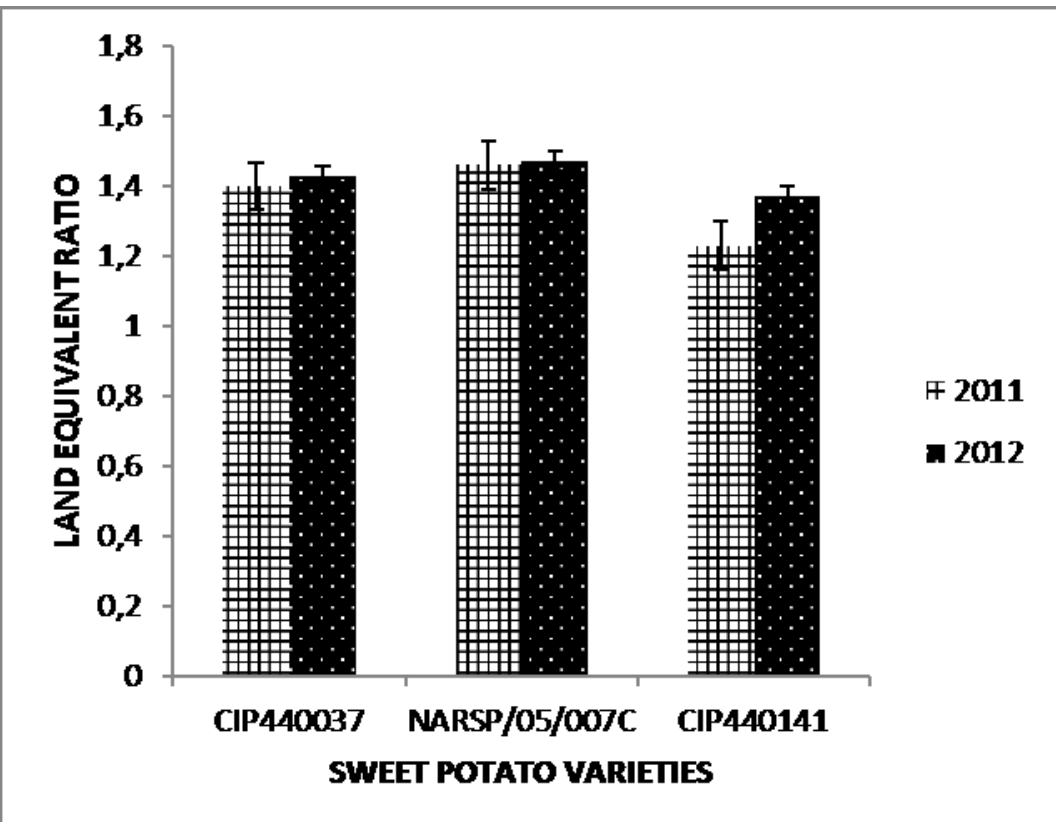

Fig.1: Land Equivalent Ratio values of sweet potato varieties intercropped with soybean in Makurdi in 2011 and 2012.

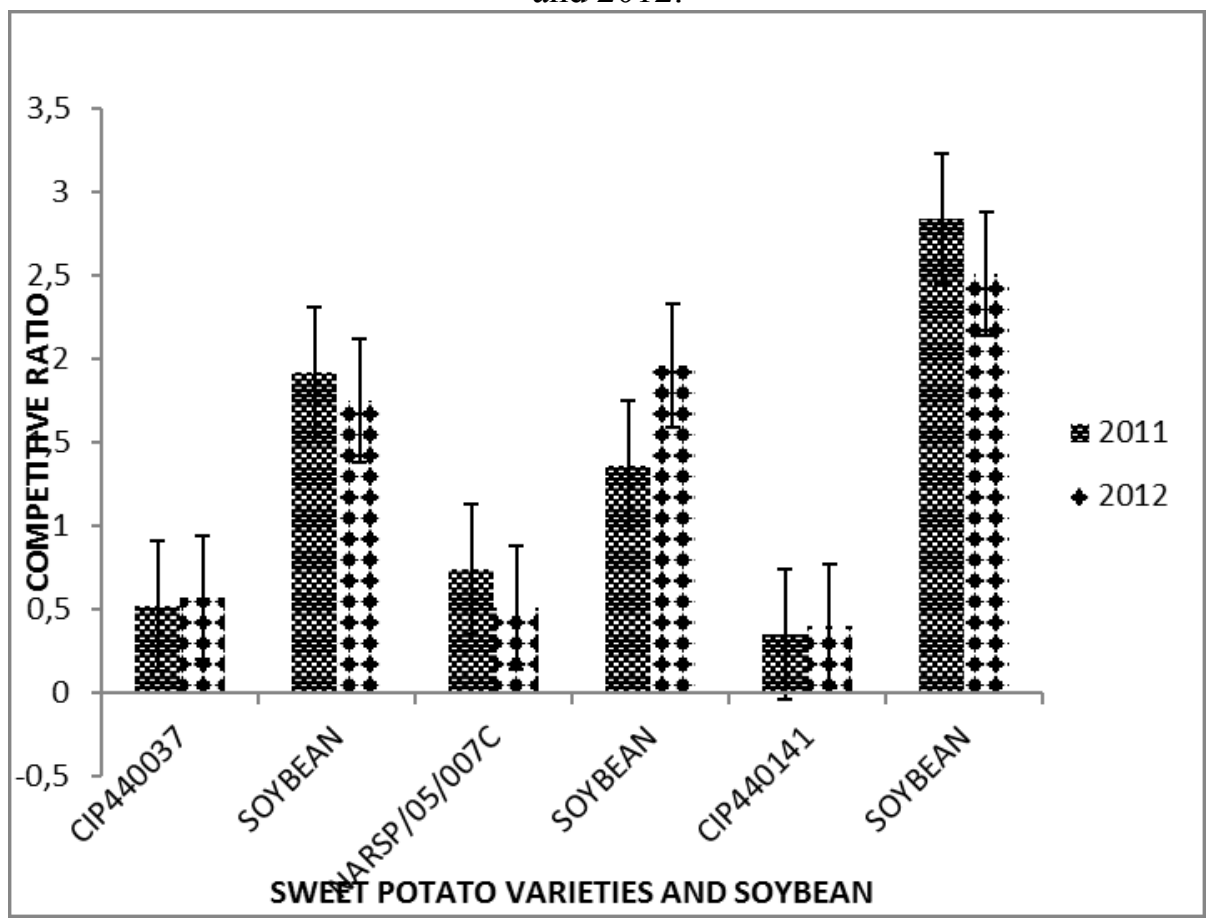

Fig. 2: Competitive ratio values of sweet potato varieties intercropped with soybean in Makurdi in 2011 and 2012. 


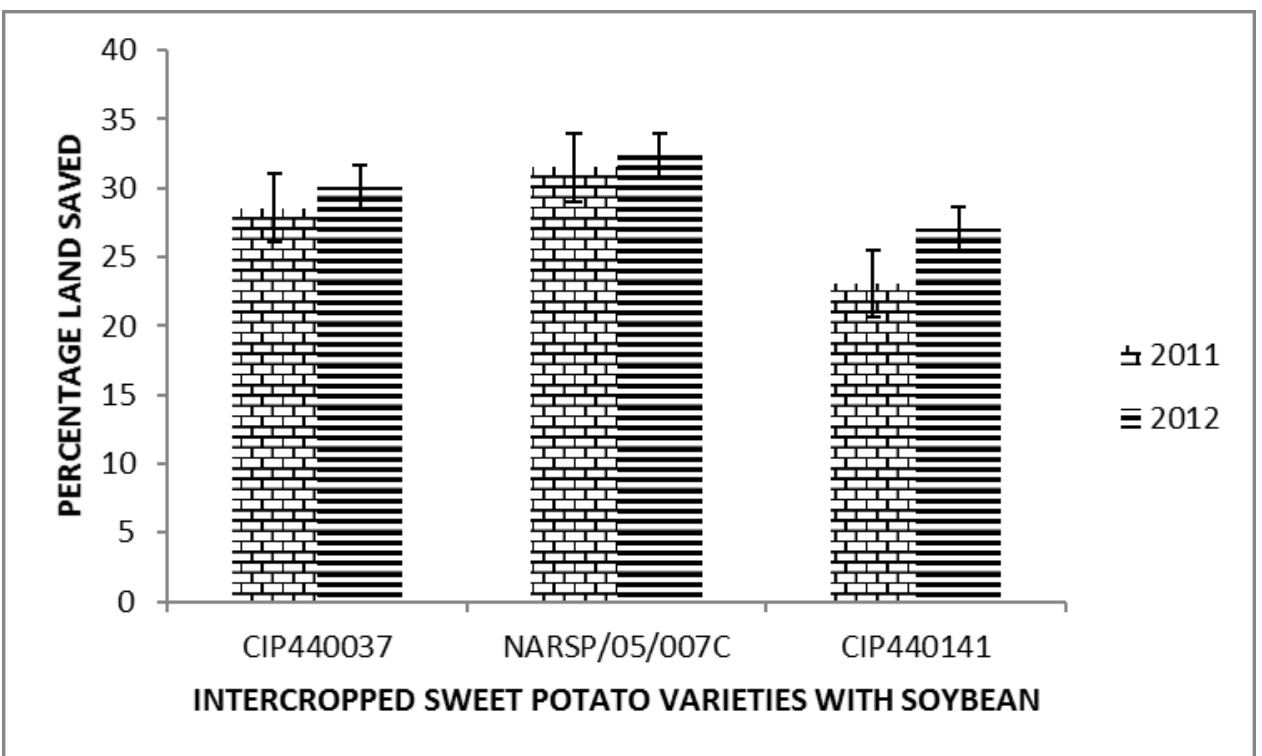

Fig.3: Percentage land saved by intercropping sweet potato varieties with soybean in Makurdi in 2011 and 2012.

\section{DISCUSSION}

The significant effects of cropping systems $\mathrm{x}$ variety on the fodder weight, number of marketable roots/plant, weight of marketable roots of sweet potato, number of pods/plant and grain yield of soybean, as well as the significant effects of cropping systems $\mathrm{x}$ density on the number and weight of marketable roots and number of pods/plant and grain yield of soybean indicated that cropping systems more than any single factor in combination with others had dominant effect on the performance of sweet potato in Makurdi, a Southern Guinea location of Nigeria. Intercropping depressed the yields of both sweet potato and the soybean components in both years of the study. This might have resulted from inter-specific competition for both above- and below- ground growth resources (sunlight, water, soil nutrients, air, etc.). The depression was severe on both intercrop components, as intercrop yields fell below $50 \%$ of sole crop values in most instances. Yield reduction is common in most intercrop studies of sweet potato and tall legumes and cereals (Egbe, 2012; Egbe and Idoko, 2009; Belehu, 2003). These authors opined that sharing growth resources among component crops under intercropping could limit growth and accumulation of dry matter compared to sole cropping where competition exists. Belehu (2003) had reported that solar radiation and soil nutrients had profound influence in the formation of preformed root primordial in sweet potato. Therefore, reduction in the availability of these growth factors might have caused the depressive root yields of the sweet potato intercrop. The mean sole crop yields $(4.11-6.44 \mathrm{t} / \mathrm{ha})$ of the sweet potato varieties evaluated in this study were low compared the existing varieties in the region, which have average yield of 9.80 t/ha (BNARDA, 2008). This low yields might make these new improved varieties unattractive and unacceptable to the farmers in the region. The insignificant reduction of the number and weight of fresh roots of intercropped sweet potato at D3 (50,000 plants/ha) and the higher percentage yield of intercrop as a proportion of sole crop yield at D3 than all other densities showed that sweet potato was more competitive with soybean at this density. It suggests that intercropping sweet potato with soybean may be more advantageous at densities $\geq 50,000$ plants/ha.

LER figures were above 1.00 for all intercrop combinations indicating advantage of intercropping these sweet potato varieties with soybean in Makurdi environment. Percentage land saved by opting for intercropping rather than sole cropping varied between 23.08 (CIP440037) and 32.43 (NARSP/05/007C). Competitive ratio values showed that the soybean component was more competitive than sweet potato, probably because of height advantage of the soybean component. Fujita et al. (1996) had reported that when component legume is taller than the non- legume under 
intercropping, the legume can grow well due to high photosynthetic activity and high biological nitrogen fixation with adequate solar radiation. These authors further stated that the non - legume growth is severely suppressed due to depression of photosynthesis through decreases in irradiance.

\section{CONCLUSION}

Intercropping depressed the yields of both sweet potato varieties and the soybean component severely, such that intercrop yields were rarely above $50 \%$ of sole crop yields, irrespective of the sweet potato variety used. The mean sole crop yields $(4.11-6.44 \mathrm{t} / \mathrm{ha})$ of the sweet potato varieties evaluated in this study were low compared the existing varieties in the region, which have average yield of $9.80 \mathrm{t} / \mathrm{ha}$, which may make it rather unattractive and unacceptable for farmers in the region to adopt. The study revealed that the number and weight of the sweet potato component was not significantly affected at the planting density of 50,000 plants/ha. Intercropping these sweet potato varieties with soybean was biologically efficient and percentage land saved varied from 23.08 and 32.43 , and soybean was more competitive than sweet potato at all densities tested.

\section{Acknowledgement.}

The authors hereby acknowledge the National Root Crops Research Institute, Umudike, Nigeria for supplying the planting materials for sweet potato without cost.

\section{References}

[1] Akunda, E. M. W. (2001). Crop yields of sorghum and soybean in an intercrop. Journal Food Tech. in Africa, 6: 2-4.

[2] Anyaebunam, H. N; Aswugba, G. N; Nwosu, K. L (2008) Guide to improved sweet potato production in Nigeria. Extension Guide $2 ; 1-2$

[3] Babatunde, F. E ; Dantata, I. J and Olawuyu, O. J (2011) Performance of sweet potato and soybeans as affected by cropping sequence in Northern Guinea Savannah of Nigeria. J. Agric. Sci. 1(3) 36-40.

[4] Baukamp,J.C. (1985). Production requirements,pp.1-33, In: J.C.Bauwkamp (ed). Sweet potato Products: A natural resource for the tropics. CRC Press, Boca Raton,FL.

[5] Belehu, T. (2003) Agronomical and physiological factors affecting growth, development and yield of sweet potato in Ethiopia. PhD Thesis, Dept. of Plant Production and Soil Science, University of Pretoria, Pretoria.

[6] BNARDA (2003). Annual report of Benue State Agricultural and Rural Development Authority, 2003. Makurdi,Nigeria, 21.

[7] BNARDA (2008). Implementation completion report reports of National Special Program for Food Security (NSPFS), Benue State Agricultural and Rural Development Authority, Makurdi, Benue State, Nigeria. pp 3 -5

[7] Bouyoucos.G.H. (1962). Hydrometer method improved for making particle size analysis of soils. Agron. J., 1(54)>465-470

[8] Bray, R.H. and Kurtz, L.T. (1945). Determination of total organic and available forms of phosphorus in soils. Soil Sci., 59: 39-45

[9] Chaykin, S. (1969). Assay of nicotinamide deaminase. Determination of ammonium by thje indolphenol reaction. Annals of Biochemistry, 32:375-382

[10] Dantata, I. J., Babatunde, F. E., Mustapha, S., Fagam, A. S. (2010) Influence of variety and plant spacing on tuber size, tuber shape and fresh marketable yield of sweet potato in Bauchi, Nigeria. Biology and Environmental Science Journal of the Tropics 7(3): 140 - 144. 
[11] Davis, J. H. C and Wooley, J. N (1993) genotype requirement for intercropping. Field crops Research, 34: 407-430.

[12] Egbe, O. M. and Idoko, J. A. (2009). Agronomic assessment of some sweet potato varieties for intercropping with pigeonpea in southern guinea savanna of Nigeria: ARPN Journal of Agriculture and Biological Sciences, 4(4): 23-32.

[13] Ennin, S. A; Ciegg, M. D and Francis, C. A (2002). Resource utilization in soybean/maize intercrop. Africa Crop Science Journal, 10(3) :251-261.

[14] Evans, A. C and Streedharan, A. (1982). Studies of intercropping 11: Castor bean with groundnut or soybeans. East Africa Agriculture and Forestry Journal, 28: 7-20.

[15] FAO (2001) FAO Production Year Book. Basic data unit, Statistics Division, FAO, Rome, Italy, 53-95.

[16] Fujita,K. and Ofosu-Budu,K.G.(1996). Significance of legumes in intercropping systems, In: Ito,O., Katayama,K., Johansen, C., Kumar Rao, J.V.D.K.., Adu-Gyamfi, J.J. and Rego,TJ (eds.) Roots and nitrogen in cropping systems of the semi-arid troipcs. JIRCAS Int. Agric. Series No.3, Japan. pp 19-40

[17] Heanes, D.L. (1984). Determination of total organic C in soils by an improved chromic digestion and spectrophotometric procedure. Communications in Soil Science and Plant Analysis, 15: 1191-1213.

[18] Henriet, J. G. A; Van, E. K; Blade, S. F and Singh, B. B (1997) Quantitative assessment of traditional cropping systems in Sudan Savannah of Nigeria 1: Rapid survey of prevalent cropping systems. Savanna Journal of Agricultural Research, 14: 27-45.

[19] Ijoyah, M. O and Jimba, J (2011). Effects of planting methods, planting dates and intercropping systems on sweet potato-okra yields in Makurdi, Nigeria.Agricultural Science Research Journal, 1 (8):184-190.

[20] Jou, A.S.R. ( 1983). Selected method for soil and plant analysis. Manual Series, No.1, Ibadan Nigeria,IITA.

[21] Njoku, S. E., Muoneke, C. O., Okpara, D. A. and Agbo, F. M. O. (2007). Effect of intercropping varieties of sweet potato and okra on ultisol of South Eastern Nigeria. Africa Journal of Biotechnology, 6(14) 1560-1654.

[22] Ofori, F. and Stern, W.R. (1987). Cereal - legume intercropping systems. Advances in Agronomy, 41: 41 - 90

[23] Onochei, B. E (1975). The potential value of soybean supplement in Nigeria diet. Proceedings of the $3^{\text {rd }}$ Annual Conference of Agricultural Society of Nigeria, 41:43-45.

[24] Ossom, E. M. (2010). Influence of sweet potato/ maize association on ecological properties and crop yields in Swaziland. International Journal of Agriculture and Biology, 12: 481488.

[25] Tel, D. and Rao, P. ( 1982). Automated and semi-automated methods for soil and plant analysis. IITA Manual Series, No. 7.

[26] Willey, R. W. (1985). An evaluation and presentation of intercropping advantage. Experimental Agriculture 21: 115-155.

[27] Willey, R. W.,Rao, M. R. (1980). A competitive ratio for qualifying competition between intercrops. Experimental Agriculture, 16: 117-125. 